\title{
EPIDEMIOLOGICAL PROFILE OF TRAUMATIC BRAIN INJURY VICTIMS OF A GENERAL HOSPITAL IN A BRAZILIAN CAPITAL
}

\author{
PERFIL EPIDEMIOLÓGICO DE VÍTIMAS DE TRAUMATISMO \\ CRANIOENCEFÁLICO DE UM HOSPITAL GERAL DE UMA CAPITAL BRASILEIRA
}

\section{Cristiane da Silva Ramos MARINHO ${ }^{1}$; Rayane Batista LEITE $^{2}$; Luiz Alves Morais FILHO ${ }^{3}$; Quenia Camille Soares MARTIN ${ }^{4}$; Cecília Nogueira VALENÇA ${ }^{5}$; \\ Osvaldo de Góes Bay JÚNIOR ${ }^{6}$; Ilisdayne Thallita Soares da SILVA ${ }^{7}$; Mayonara Fabíola Silva ARAÚJO ${ }^{8}$; Rafaela Carolini de Oliveira TÁVORA ${ }^{9}$; Mayara Silva Fernandes do RÊGO ${ }^{10}$; Fábia Cheyenne Gomes de Morais FERNANDES ${ }^{11}$; Maria Leonor Paiva da SILVA ${ }^{12}$; Renata Fonseca Sousa de OLIVEIRA ${ }^{13}$}

1. Mestre em Enfermagem. Professora do Curso de Enfermagem da Faculdade de Ciências da Saúde do Trairi/Universidade Federal do Rio Grande do Norte (FACISA/UFRN). cristiane_ramos@hotmail.com; 2. Especialista em Saúde Coletiva. Faculdade de Ciências da Saúde do Trairi/Universidade Federal do Rio Grande do Norte (FACISA/UFRN); 3. Doutor em Enfermagem. Professor do Curso de Enfermagem da Faculdade de Ciências da Saúde do Trairi/Universidade Federal do Rio Grande do Norte (FACISA/UFRN); 4. Doutor em Ciências Médicas. Professora do Curso de Enfermagem da Faculdade de Ciências da Saúde do Trairi/Universidade Federal do Rio Grande do Norte (FACISA/UFRN); 5. Doutor em Enfermagem. Coordenadora do Curso de Pós-Graduação em Saúde Coletiva da Faculdade de Ciências da Saúde do Trairi/Universidade Federal do Rio Grande do Norte (FACISA/UFRN); 6. Mestre em Enfermagem. Professor do Curso de Enfermagem da Faculdade de Ciências da Saúde do Trairi/Universidade Federal do Rio Grande do Norte (FACISA/UFRN); 7. Mestre em Enfermagem. Faculdade de Ciências da Saúde do Trairi/Universidade Federal do Rio Grande do Norte (FACISA/UFRN); 8. Especialista em Saúde Pública. Faculdade de Ciências da Saúde do Trairi/Universidade Federal do Rio Grande do Norte (FACISA/UFRN); 9. Doutor em Enfermagem. Professora do Curso de Enfermagem da Faculdade de Ciências da Saúde do Trairi/Universidade Federal do Rio Grande do Norte (FACISA/UFRN); 10. Professora do Curso de Enfermagem da Faculdade de Ciências da Saúde do Trairi/Universidade Federal do Rio Grande do Norte (FACISA/UFRN); 11. Professora do Curso de Enfermagem da Faculdade de Ciências da Saúde do Trairi/Universidade Federal do Rio Grande do Norte (FACISA/UFRN); 12. Mestre em

Enfermagem. Professora do Curso de Enfermagem da Faculdade de Ciências da Saúde do Trairi/Universidade Federal do Rio Grande do Norte (FACISA/UFRN); 13. Mestranda do Programa de Pós-Graduação em Saúde Coletiva da Faculdade de Ciências da Saúde do Trairi/ Universidade Federal do Rio Grande do Norte (FACISA/UFRN).

\begin{abstract}
In Brazil, the accidents and urban violence, the external causes, build a public health problem that has taken big proportions and transcendence, with a big impact on the population's lives. In the set of injuries resulting from external causes, the Traumatic brain injury (TBI) stands out in terms of magnitude, both among dead and injured, being one of the most frequent injuries. Thus, it is important to know epidemiological profile of traumatic brain injury victims, local characteristics, in order to take more effective prevention actions based on this reality, since the primary causes of TBI can vary according to the people involved. The objective of this study was to know the epidemiological profile of traumatic brain injury victims, the type of causative event and the severity of the trauma. Exploratory, crosssectional, quantitative and descriptive research, conducted with 372 patients suffering from traumatic brain injury. Data were collected from form itself, semi-structured form, and analyzed using the SPSS 20.0 software. The research had the project approved by the Research Ethics Committee, CAAE 30487514.6.0000.5568. There was a predominance of males, aged 18-30 years. The cause of the most common brain injury was traffic accident with a prevalence of moderate traumatic brain injury. It is necessary to the development of preventive actions as well as the development of public policies that contribute to the reduction of morbidity and mortality from TEC and qualified assistance to victims.
\end{abstract}

KEYWORDS: Injuries stroke. Glasgow coma scale. Epidemiology.

\section{INTRODUCTION}

In Brazil, the accidents and urban violence, the external causes, build a public health problem that has taken big proportions and transcendence, with a big impact on the population's lives (CANOVA et al, 2010).

The Brazilian statistics show that external causes are the fourth most frequent mortality cause in the country (BRASIL, 2010). However, the consequences of traumas are not limited in death, many surviving victims remain disabled for a long time, or permanent physical and cognitive sequelae (SOUSA, 2006).

In the set of injuries resulting from external causes, the Traumatic brain injury (TBI) stands out in terms of magnitude, both among dead and injured, being one of the most frequent injuries(CANOVA et al, 2010). It represents approximately $15 \%$ to $20 \%$ of deaths in people aged 5 to 35 years, being responsible for the mortality of $1 \%$ of all adults (GENTILE et al., 2011). 
It is estimated there are about 1.4 million people in the United States of America (USA) suffering from TBI each year. Of these, 235,000 are hospitalized, 80,000 have permanent disability and 50,000 die. [5]

Thus, it can be said that the TBI is a phenomenon capable of initiate disabilities in its victims, ranging from temporary to permanent, interfering with the individuals' ability to perform their functions (CANOVA et al, 2010).

Conceptually, the TBI can be defined as any injury that causes anatomical injury or functional impairment of the scalp, skull, meninges, or brain (CANOVA et al, 2010). This is a complex pathophysiological process, that includes multiple reactions, which cause changes in brain hemodynamics, cellular and molecular changes, and cerebral edema and intracranial hypertension. In severe brain lesions, capable of eliciting coma, it is known that there is a reduction of approximately $50 \%$ of cerebral blood flow during the first 6 to 12 hours post-trauma (FERIANI et al., 2013).

Regarding the gravity, the TBI can be classified as light, moderate or severe. For this, the Glasgow Coma Scale (GCS) can be used as a measurement instrument, where values assigned by the scale between 13 and 15 points classify TBI as light, between 9 and 12 points as moderate and between 3 and 8 points as severe (ANDRADE et al., 2009).

The first 72 hours post-trauma have a big importance in the evolution of TBI victims, bringing valuable information about how severe it is, because of the pathophysiological events that may occur during this period (SETTERVALL, SOUSA, 2012).

The initial moments after the impact, both on the site of trauma occurrence or in hospital, represent a critical stage in the pathophysiology of the brain injury. When an appropriate care are realized in an appropriate time, it can improve the neurological prognosis significantly. Therefore, delay or failure in the institution of these actions may result in secondary brain insults, with devastating consequences for the later recovery of neurological functions (PEREIRA et al., 2011).

Thus, it is important to know local characteristics, in order to take more effective prevention actions based on this reality, since the primary causes of TBI can vary according to the people involved. In this way, the study aimed to understand the epidemiological profile of traumatic brain injury victims, the type of causative event and the severity of the trauma in a general hospital in the city of Natal, Rio Grande do Norte, Northeastern Brazil.

\section{MATERIAL AND METHODS}

This was an exploratory, cross-sectional survey with a quantitative approach, descriptive character, performed with 372 patients suffering from TBI, in the period from July to October 2014.

The study was conducted in a general hospital in the city of Natal, Rio Grande do Norte $(\mathrm{RN})$, Northeastern Brazil, which is a reference in emergency care with the Unified Health System (SUS) in the state, being the only public hospital in the metropolitan region of Natal that has service for burned people, orthopedics, neurology and neurosurgery.

This hospital meets monthly, an average of 21,000 patients coming from the capital and the country, which 1,100 are hospitalized. Each month, are made about 600 surgical procedures, including surgeries and orthopedic reductions.

For the sample calculation was taken as a basis: a sampling error of $5 \%$ and the number of neurological patients assisted in 2013, which according to the report prepared by the Hospital Epidemiology Center, were 5,127 neurological patients between months from January to December 2013.

For data collection were adopted the following eligibility criteria: TBI victims, aged over 18 years, who were at the institution during the first 72 hours after the event, which had notes in their files about ECGI time admission and, in case of coma or verbal communication impossible, the people who had companion.

Data were collected from its semi-structured form, composed of question for characterization of the victims of TBI, information about the cause of the trauma and its severity. The medical records of the victims were also consulted for additional information. The data were categorized and processed electronically through the software Statistical Package for Social Sciences (SPSS) version 20.0. Through the results, were made descriptive analysis of the study variables with relative and absolute frequency.

The survey was conducted in compliance with the ethical aspects of research involving humans, recommended by the National Health Council (CNS) 466/12, being registered in Brazil Platform and appreciated by the Research and Ethics Committee of the Trairi Health Sciences College (FACIS) / Federal University of Rio Grande do Norte (UFRN), with number of CAAE 30487514.6.0000.5568. All participants signed the Free Consent and Informed Term (TCLE). 


\section{RESULTS}

From the 372 victims of TBI surveyed, the majority are male $(85.2 \%)$ and aged between 18 and 30 years $(56.2 \%)$, as shown in Table 1 .

Table 1. Distribution of victims of traumatic brain injury by gender, age and education. Natal, RN, Brazil, in 2014.

\begin{tabular}{lcc}
\hline \multicolumn{1}{c}{ Variables } & N & \% \\
\hline Gender & 317 & 85,2 \\
Male & 55 & 14,8 \\
Female & 372 & 100 \\
$\quad$ Total & & \\
\hline Age Group & 209 & 56,2 \\
18 - 30 years old & 84 & 22,6 \\
$31-40$ years old & 36 & 9,7 \\
41 - 50 years old & 22 & 5,9 \\
51 - 60 years old & 21 & 5,6 \\
Above 61 years old & 372 & 100 \\
$\quad$ Total & & \\
\hline Education & 16 & 4,3 \\
Unlettered & 12 & 3,2 \\
Incomplete primary education I & 11 & 3 \\
Complete primary education I & 11 & 3 \\
Incomplete primary education II & 29 & 7,8 \\
Complete primary education II & 64 & 17,2 \\
Incomplete High School & 212 & 57 \\
Complete High School & 15 & 4 \\
Incomplete College & 2 & 0,5 \\
Complete College & 372 & 100 \\
$\quad$ Total & & \\
\hline
\end{tabular}

Regarding the average age of the surveyed, it was found an average of 34.08 years and a mean standard deviation \pm 12.79 years.

Regarding the education, the Table 1 shows that with the surveyed, the highest percentage are patients with high school completed (57\%), while the lowest percentage are patients with college completed $(0.5 \%)$.

Regarding the sex and type of event, the Table 2 shows that traffic accidents (automobile and motorcycle) and falls were the most external causes that caused TBI in both sexes, accounting respectively for $71.6 \%$ and $12.9 \%$ of TBI cases.

Analyzing the day and time range which happen the cause of TBI events, it shows that the Friday appears as the day responsible for the largest number of TBI cases (18.5\%), followed by Monday $(17.5 \%)$, as shown in Table 3. It is noteworthy that $43.1 \%$ of TBI injuries happened during the early hours of Monday. This data is not mentioned in the Table. In the remaining days can be noted that the time between $12 \mathrm{pm}$ and 5:59pm stood out. 
Tabel 2. Distribution of victims of traumatic brain injury according to the gender and type of accident. Natal, $\mathrm{RN}$, Brazil, in 2014.

\begin{tabular}{|c|c|c|c|c|c|c|}
\hline \multirow{3}{*}{ Type of Accident } & \multicolumn{4}{|c|}{ Gender } & \multirow{2}{*}{\multicolumn{2}{|c|}{ Total }} \\
\hline & \multicolumn{2}{|c|}{ Male } & \multicolumn{2}{|c|}{ Female } & & \\
\hline & $\mathbf{N}$ & $\%$ & $\mathbf{N}$ & $\%$ & $\mathbf{N}$ & $\%$ \\
\hline Automobile Accident & 87 & 23,4 & 8 & 2,2 & 95 & 25,6 \\
\hline Motorcycle Accident & 145 & 39 & 29 & 7 & 174 & 46 \\
\hline Falls & 35 & 9,40 & 13 & 3,5 & 48 & 12,9 \\
\hline Firearms & 31 & 8,30 & 2 & 0,5 & 33 & 8,8 \\
\hline Agression & 19 & 5,10 & 3 & 0,8 & 22 & 5,9 \\
\hline Total & 317 & 85,20 & 55 & 4,8 & 372 & 100 \\
\hline
\end{tabular}

Table 3. Distribution of victims of traumatic brain injury according day and time of the accident. Natal, RN, Brazil, in 2014.

\begin{tabular}{|c|c|c|c|c|c|c|c|c|c|c|}
\hline \multirow{4}{*}{$\begin{array}{l}\text { Day the } \\
\text { accident } \\
\text { happend }\end{array}$} & \multicolumn{8}{|c|}{ Time of the Accident } & \multirow{3}{*}{\multicolumn{2}{|c|}{ Total }} \\
\hline & \multirow{2}{*}{\multicolumn{2}{|c|}{$\frac{\text { Dawn }}{(12 \mathrm{am}-05: 59 \mathrm{am})}$}} & \multirow{2}{*}{\multicolumn{2}{|c|}{$\begin{array}{c}\text { Morning } \\
\text { (06am-11:59am) }\end{array}$}} & \multirow{2}{*}{\multicolumn{2}{|c|}{$\begin{array}{c}\text { Afternoon } \\
\text { (12pm-17:59pm) }\end{array}$}} & \multirow{2}{*}{\multicolumn{2}{|c|}{$\begin{array}{c}\text { Night } \\
(6 \mathrm{pm}-11: 59 \mathrm{pm})\end{array}$}} & & \\
\hline & & & & & & & & & & \\
\hline & $\mathbf{N}$ & $\%$ & $\mathbf{N}$ & $\%$ & $\mathbf{N}$ & $\%$ & $\mathbf{N}$ & $\%$ & $\mathbf{N}$ & $\%$ \\
\hline Sunday & 1 & 0,3 & 6 & 1,6 & 28 & 7,5 & 16 & 4,3 & 51 & 13,7 \\
\hline Monday & 29 & 7,8 & 9 & 2,4 & 19 & 5,1 & 8 & 2,2 & 65 & 17,5 \\
\hline Tuesday & 1 & 0,3 & 12 & 3,2 & 27 & 7,3 & 11 & 3 & 51 & 13,7 \\
\hline Wednesday & 0 & 0 & 6 & 1,6 & 21 & 5,6 & 7 & 1,9 & 34 & 9,1 \\
\hline Thursday & 0 & 0 & 4 & 1,1 & 22 & 5,9 & 20 & 5,4 & 46 & 12,4 \\
\hline Friday & 3 & 0,8 & 13 & 3,5 & 31 & 8,3 & 22 & 5,9 & 69 & 18,5 \\
\hline Saturday & 2 & 0,5 & 8 & 2,2 & 30 & 8,1 & 16 & 4,3 & 56 & 15,1 \\
\hline Total & 36 & 9,7 & 58 & 15,6 & 178 & 47,8 & 100 & 26,9 & 372 & 100 \\
\hline
\end{tabular}

Regarding the transport of the victims of TBI, it was observed that the locomotion of them to the hospital, mostly, was performed using the Prehospital Care (APH), as shown in Figure 1.
Regarding the severity of the trauma, most the cases are the moderate TBI with $61.3 \%$, as shown in Figure 2.

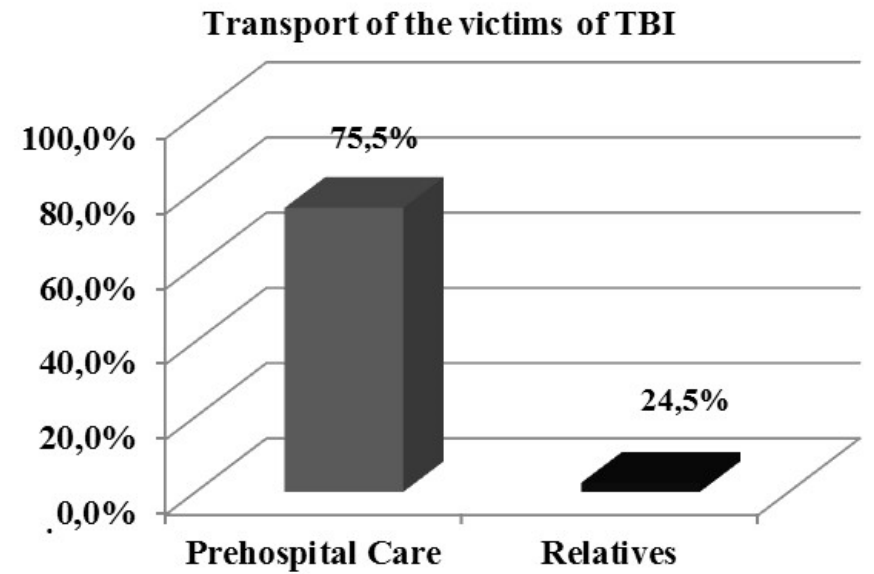

Figure 1. Distribution of victims of traumatic brain injury according to the responsible for making transportation to the health service. Natal, Brazil, in 2014. 


\section{Trauma Severity and Type of Event}

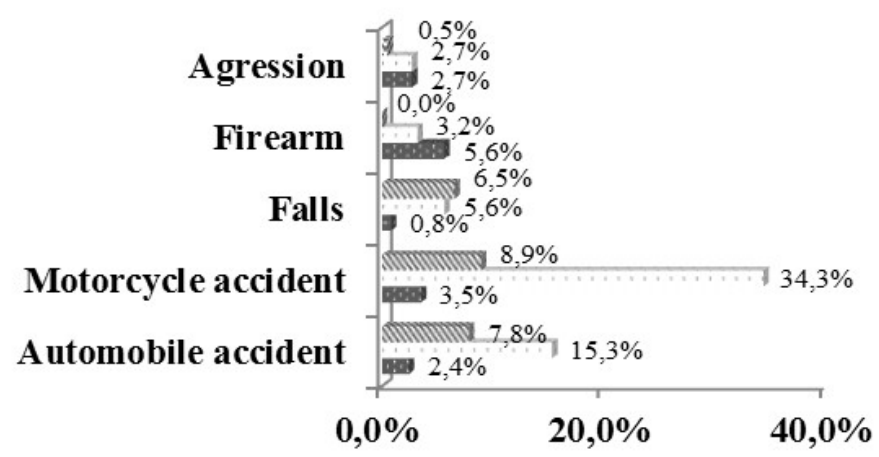

\section{Light TBI Moderate TBI 해 Severe TBI}

Figure 2. Distribution of victims of traumatic brain injury according to trauma severity and type of event. Natal, RN, Brazil, in 2014.

\section{DISCUSSION}

Knowing the profile of the patients treated in each service is essential because the clarification of the epidemiological and event data is an important step for the development of preventive actions and improvement of care.

In the survey, there was a predominance of males aged between 18 and 30 years, corresponding to $50 \%$ of all victims of TBI, corroborating studies (ANDRADE et al. , 2009; SOARES, RODRIGUES JÚNIOR, 2012), which predominated the young male population as a victim of this disease. It is believed that this result is justified by the higher exposure of men to risk factors associated to the trauma, possibly by lifestyle and social context which they are inserted (ELOIA et al., 2011).

Other researches (VIEIRA ET AL., 2011; GOMES et al., 2014) relate this predominance of young males to the immaturity of age, selfconfidence and tendency to challenge the limits.

It is important to observe that a study made with victims treated by the Wandering Emergency Service Care in Campo Grande, Mato Grosso, Brazil also viewed a higher exposure to violence of males, still in their teens and young adults, which, on the other hand, remember that it can be also linked not only to social problems such as the lack of well-defined life projects (SANCHES, DUARTE, PONTES, 2008).

By reaching an age group that corresponds to the portion of the economically active population, at the peak of their abilities, it ends up generating a negative impact on the economy, because a large number of socially active people remains incapacitated for a varied period of time or permanently, which brings a high social cost (LOPES, COSTA, CARVALHO, 2013).

Regarding the education, there was a predominance of victims with complete high school, which is different from a study (FARIAS et al, 2009) that dealt with the severity of the injury with motorcycle drivers victims of traffic accident in the state of RN, Brazil, where it showed that, from 371 victims, $37.47 \%$ had incomplete primary education, and only $26.68 \%$ had completed high school. It is believed that the increase of the victims' educational level is due to the increased accessibility to the educational institutions, and because the job market demand, which is larger for more educated people.

Regarding the gender and type of event occurred, it was noteworthy that motorcycle accidents predominated in both sexes, this factor can be associated with the uncontrollable growth of the motorcycle fleet, encouraged by the ease of purchase, where these vehicles are becoming more accepted by the population, due to its agility (LOPES, COSTA, CARVALHO, 2013).

The predominance of motorcycle accidents as an external cause, found in this research, shows the need for a more efficient solution to this problem, which affects the population's daily life. Actions need to be implemented, such as: encouraging and supporting the development of researches considered strategic, especially those linked to behavior in traffic, risk of accidents due to vehicle conditions and improper use of safety equipment, articulate people in the education, justice and public safety sectors, trying to create cooperation protocols in order to prevent these accidents (SOARES, J. S., RODRIGUES JÚNIOR, 2012). 
Other researche have already highlighted the possible relationship between blood alcohol levels and traffic accidents, since the consumption of beverages at festive or celebratory events, in which young people abuse alcohol without moderation, favors drowsiness and the occurrence of accidents (ABREU et al., 2010).

In addition, a predominance of TBI by firearms and aggression in males has been identified, which shows that this is a group more exposed to social problems. Besides that, the "machista culture", still prevalent in society, which imposes that men has more freedom, and must always "defend his honor", which makes them more vulnerable (SANCHES, DUARTE, PONTES, 2008).

Regarding the day of the week that the TBI occurred, it was observed that the higher incidence of these events was between Friday evening and Monday morning $(42.5 \%)$. It is believed this is due to the weekend, which is responsible for a larger number of festive events, use of alcohol, and people are exempted from their daily obligations, as study and work, which brings both an increase in the number accidents of transit, as well as assaults and accidents with firearms.

For the time, it was observed that most cases of TBI occurred between $12 \mathrm{pm}$ and $5: 59 \mathrm{pm}$, similar data from another research (ANDRADE et al, 2009). It happens probably because this is the rush time going to work and school, or returning from these places. It is believed that, in addition to the increased flow of vehicles, the physical stress associated with a exhausting day of work, associated with insecurity in traffic leads to increased vulnerability to accidents.

It is also worth to highlight that there was a significant number of cases that occurred between $6 \mathrm{pm}$ and 11:59pm, which was found in another study (BARBOSA et al., 2010), this time is associated with festive events and alcohol consumption.

With regard to victim transportation it was observed that the Prehospital Care was responsible for most of it, representing $75.5 \%$ of the total victims transported to the health service. It is believed this is justified by the fact that the Prehospital Care has grown with the Wandering Emergency Service Care (SAMU) and the credibility gained by the service with the Brazilian population, which currently serves $72 \%$ of the population, benefiting 140 million people served in 2,660 cities, reducing the number of deaths, hospitalization and sequelae arising from the lack of early care (BRASIL, 2013).
Today there are, throughout Brazil, 3,041 ambulances and 182 regulation plants in operation. In 2003, there were only 309 vehicles, covering $13 \%$ of the citizens. After ten years, the number of ambulances increased approximately 10 times and increased coverage in 440\% (BRASIL, 2013).

Regarding the Rio Grande do Norte state, nowadays there are 25 decentralized SAMU central, which cover 60 cities, serving an average of two million people, reaching a coverage of $75 \%$ of the state population, highlighting the data found in the research.

As regards the severity of the trauma it is evident that the victims of TBI who were studied were frequently involved with higher severity events, highlighting motorcycle accidents, which can be easily found if we count the total number of severe and moderate TBIs and compare them with the TBIs defined as light, which showed values of $15.1 \%, 61.3 \%$ and $23.7 \%$ respectively.

Similar results were found in research that dealt with the epidemiological profile of patients with TBI in the city of Teresina, Piauí, where the moderate TBIs accounted for 1,046 hospitalizations in 2012, while for the light and severe TBIs were registered respectively, in the same year, 301 and 35 cases (LOPES, COSTA, CARVALHO, 2013).

It is believed this study results are arising from traffic accidents, the event that caused more TBI cases, especially the motorcycle, that causes a higher exposure of their victims, encouraging a higher severity of the trauma.

The research shows as a limitation the sampling for convenience, since there were not enough human resources to make the data collection during the 24 hours of the day. In addition, there was not the application of statistical tests to verify the association between the variables and its significance.

\section{CONCLUSIONS}

The most of TBI patients treated in a hospital in the city of Natal are male, belonging to the age group 18-30 years, with completed high school.

The most common etiology of TBI was from traffic accidents, followed by falls, which occurred mostly during the weekends in the afternoon and at night.

As regards the transport of TBI victims, it was observed that the Prehospital Care/SAMU was responsible for moving the victim from the accident to the health service care. 
Speaking about severity, it was noticed that the victims were mostly stricken by the moderate TBI, followed by light and severe. Therefore, the results showed in this work become relevant for the service, because it can invest more in actions that are necessary to serve the victims affected by TBI, allowing it to perform a better care. This research presents as a limitation the absence of statistical test.

It is also noteworthy the need to implement a care protocol for patients with TBI in the studied institution, and train professionals for its occurrence, in order to provide a better assistance to victims of this pathology, since the correct care is directly related to these patients' prognosis.
It is also noticed that there is a need for an awareness campaign aiming the society in general, but, mainly, to the people who use motorcycle as a transportation, since the TBI cases were mostly coming from accidents involving it. Therefore, it is essential and immediate the adoption of social and educational actions and a more active surveillance, in order to ensure the correct behavior of people in the traffic, aiming to reduce and prevent accidents. It is expected that the results can stimulate and support future research in this area, since the development of studies focusing this theme will contribute to the formulation of this disease coping strategies.

RESUMO: No Brasil, os acidentes e a violência urbana, ou seja, as causas externas configuram um problema de saúde pública que tem tomado grandes proporções e transcendência, com forte impacto na vida da população. No conjunto de lesões decorrentes das causas externas, o Traumatismo Cranioencefálico (TCE) destaca-se em termos de magnitude, tanto entre mortos quanto em feridos, sendo uma das lesões mais frequentes. Assim, é de fundamental importância o conhecimento do perfil epidemiológico das vítimas das de traumatismo cranioencefálico, as características locais, para que sejam, então, adotadas medidas de prevenção mais efetivas baseadas nessa realidade, uma vez que as causas primárias do TCE variam de acordo com a população envolvida. O estudo pretende conhecer o perfil epidemiológico das vítimas de traumatismo cranioencefálico, o tipo de evento causador e a gravidade do trauma. Pesquisa exploratória, transversal, quantitativa e descritiva, realizada com 372 pacientes vítimas de traumatismo cranioencefálico. Os dados foram coletados a partir de formulário próprio, semiestruturado, e analisados por meio do software SPSS 20.0. A pesquisa teve o projeto aprovado pelo Comitê de Ética em Pesquisa, CAAE 30487514.6.0000.5568. Houve predomínio do sexo masculino, na faixa etária de 18 a 30 anos. A causa do traumatismo cranioencefálico mais frequente foi a de acidentes de trânsito, havendo predomínio do traumatismo cranioencefálico moderado. Faz-se necessário o planejamento de ações preventivas, bem como o desenvolvimento de políticas públicas que contribuam com a diminuição da morbimortalidade por traumatismo cranioencefálico e com o atendimento qualificado às vítimas.

PALAVRAS-CHAVE: Traumatismos encefálicos. Escala de coma de Glasgow. Epidemiologia.

\section{REFERENCES}

ABREU, A. M. M. et al . Uso de álcool em vítimas de acidentes de trânsito: estudo do nível de alcoolemia. Rev. Latino-Am. Enfermagem, v. 18, n. spe, p. 513-520, 2010 . Disponível em $<$ http://www.scielo.br/scielo.php?script=sci_arttext\&pid=S0104-11692010000700005\&lng=en\&nrm=iso $>$. Acesso em: 01 Dec. 2016.

ANDRADE, A. F. et al. Mecanismos de lesão cerebral no traumatismo cranioencefálico. Rev Assoc Med Bras., v. 55, n. 1, p. 75-81, 2009. Disponível em:< http://www.scielo.br/pdf/ramb/v55n1/v55n1a20.pdf>. Acesso em: 8 de agosto de 2016.

ANDRADE, L. M. et al. Acidentes de motocicleta: características das vítimas e dos acidentes em hospital de Fortaleza - CE, Brasil. Rev Rene, v. 10, n. 4, p. 52-9, 2009. Disponível em:

$<$ http://www.repositorio.ufc.br/bitstream/riufc/4411/1/2009_art_malima.pdf $>$. Acesso em: 23 de setembro de 2016.

BARBOSA, S. L. et al. Fatores desencadeantes ao trauma cranioencefálico em um hospital de emergência municipal. Rev Baiana Saude Publica. 2010 v. 34, n. 2, p. 240-53, 2010. Disponível em: <http://files.bvs.br/upload/S/0100-0233/2010/v34n2/a1795.pdf>. Acesso em: 23 de setembro de 2016.

BRASIL. Ministério da Saúde. Departamento de Informática do SUS (DATASUS). Informações de saúde: estatísticas vitais. Brasília, DF, 2010. 
BRASIL. Portal da Saúde. Radar Saúde Congresso. Boletim informativo do ministério da saúde destinado aos parlamentares. v. 3, n. 135, 2013. Disponível em: http://u.saude.gov.br/images/pdf/2013/dezembro/19/radarsaude-n172.pdf. Acesso em: 17 de julho de 2016.

CANOVA, J. C. M. et al. Traumatismo cranioencefálico de pacientes vítimas de acidentes de motocicletas. Arq Ciênc Saúde, v. 17, n. 1, p. 9-14, jan-mar, 2010. Disponível em: <http://repositorioracs.famerp.br/racs_ol/vol-17-1/IDL_jan-mar_2010.pdf>. Acesso em: 10 de julho de 2016.

ELOIA, S. C et al. Análise epidemiológica das hospitalizações por trauma cranioencefálico em um hospital de ensino. Rev Sanare, v. 10, n. 2, p. 34-9, 2011. Disponível em:

<http://sanare.emnuvens.com.br/sanare/article/view/253/226>. Acesso em: 12 de agosto de 2016.

FARIAS, G. M. et al. Characterization of motorcycle drivers involved in traffic accidents attented at urgency hospital. Rev Enferm UFPE on line, v. 3, n. 4, p. 898-907, 2009. Disponível em:

<http://www.revista.ufpe.br/revistaenfermagem/index.php/revista/article/download/99/2924>. Acesso em: 12 de agosto de 2016.

FERIANI, G. et al. Pré Hospitalar: Grau. 1ª ed. Barueri: Manole, 2013.

GENTILE, J. K. A. et al. Condutas no paciente com trauma cranioencefálico. Rev Bras Clin Med., v. 9, n. 1, p. 74-82, 2011. Disponível em: <http://files.bvs.br/upload/S/1679-1010/2011/v9n1/a1730.pdf>, Acesso em: 10 de setembro de 2013.

GOMES, S. L. et al.. Perfil das vítimas de acidentes motociclísticos admitidas nas Terapias intensivas de um hospital público. Rev Enferm UFPE on line, v. 8, n. 7, p. 2004-12, 2014. Disponível em: $<$ http://www.revista.ufpe.br/revistaenfermagem/index.php/revista/article/download/4747/9541>. Acesso em: 15 de outubro de 2014.

LOPES, R. D., COSTA, P. P., CARVALHO, F. T. Perfil epidemiológico dos pacientes acometidos por trauma cranioencefálico assistidos em um hospital público de Teresina. Rev bras neurol psiquiatr, v. 7, n. 3, p. 80-90, 2013. Disponível em:

$<$ http://www.submit.10envolve.com.br/uploads/5d99ef829dd033512768311c2cb7e235.pdf>. Acesso em: 30 de outubro de 2014.

PEREIRA, N. et al. Assistência de enfermagem prestada à vítima de traumatismo crânio-encefálico em jovens e adultos. Rev Interd Novafapi, v. 4, n. 3, p. 60-5, 2011. Disponível em:

<http://www.novafapi.com.br/sistemas/revistainterdisciplinar/v4n3/revisao/rev4_v4n3..pdf>. Acesso em: 10 de agosto de 2014.

RIO GRANDE DO NORTE. Secretaria da Saúde Pública. [. SAMU- Serviço de atendimento móvel de urgência. 2013. Disponível em:

http://saude.rn.gov.br/Conteudo.asp?TRAN=ITEM\&TARG=2370\&ACT=\&PAGE=\&PARM=\&LBL=NOT\%C DCIA. Acesso em: 17 de novembro de 2014.

SANCHES, S., DUARTE, S. J. H., PONTES. E. R. J. C. Caracterização das vítimas de ferimentos por arma de fogo, atendidas pelo serviço de atendimento móvel de urgência em Campo Grande-MS. Rev Saúde Soc., v. 18, n. 1, p. 95-102, 2008. Disponível em: <http://www.scielo.br/pdf/sausoc/v18n1/10.pdf >. Acesso em: 10 de novembro de 2014.

SETTERVALL, C. H. C., SOUSA, R. M. C. Escala de coma de Glasgow e qualidade de vida pós-trauma cranioencefálico. Acta Paul Enferm. v. 25, n. 3, p. 364-70, 2012. Disponível em:

$<$ http://www.scielo.br/pdf/ape/v25n3/v25n3a08.pdf>. Acesso em: 10 de agosto de 2014.

SMELTZER, S. C. et. al,. Tratado de Enfermagem Médico-Cirúrgico. 11ª ed. Rio de Janeiro: Guanabara Koogan, 2011. 
SOARES, J. S., RODRIGUES JÚNIOR, N. S. Perfil epidemiológico do traumatismo cranioencefálico em unidade de terapia intensiva. Rev Piauiense de Saúde, v. 1, n. 2, p: 17-23, 2012. Disponível em: $<$ http://www.revistarps.com.br/index.php/rps/article/view/12/10>. Acesso em: 20 de outubro de 2014.

SOUSA, R. M. C. Comparação entre instrumentos de mensuração das consequências do trauma cranioencefálico. Rev Esc Enferm USP, v. 40, n. 2, p. 203-13, 2006. Disponível em:<http://www.scielo.br/pdf/reeusp/v40n2/07.pdf $\geq$. Acesso em: 10 de setembro de 2014

VIEIRA, R. C. A. et al. Levantamento epidemiológico dos acidentes motociclísticos atendidos em um Centro de Referência ao Trauma de Sergipe. Rev Esc Enfermagem USP. v. 45, n. 6, p. 1359-63, 2011. Disponível em: <http://www.scielo.br/pdf/reeusp/v45n6/v45n6a12.pdf>. Acesso em: 15 de outubro de 2014. 